\title{
Estimation of Different Uniformities and Distribution Characteristic of Automated and Conventional Drip Irrigation Systems for Okra Crop under Field Condition
}

\author{
Vikas Sharma ${ }^{1}$, Yadvendra Pal Singh ${ }^{1}$, Manpreet Kaur ${ }^{2}$ and V.D. Paradkar ${ }^{1}$
}

${ }^{1}$ Department of Soil and Water Engineering, ${ }^{2}$ Department of Textiles and Apparel Designing, Maharana Pratap University of Agriculture and Technology, Udaipur, Rajasthan, 313001, India

*Corresponding author

A B S T R A C T

\section{Keywords}

Micro controller,

Timer, Automated drip irrigation,

Emission uniformity, Hydraulic

performance, Sensor

Article Info

Accepted:

17 June 2019

Available Online:

10 July 2019
The study was conducted at Technology Park (Plasticulture Farm) of CTAE, Udaipur, Rajasthan to evaluate performance of automated and conventional drip system for okra crop during year 2019. The Uniformity Coefficient (CU), Distribution Characteristic (DC) and Emission Uniformity (EU) were found to be highest at the head and decreases with increase in distance along the lateral for both irrigation systems. It was found that the average values of all evaluation parameters except DC, were found to be highest for automated drip system. The values of EU were more than to design criteria of $90 \%$ in each condition Keller and Karmeli (1974) for installed drip irrigation systems, which indicate that both drip systems operated excellently.

\section{Introduction}

The population of India is increasing rapidly day by day so the pressure on agriculture to fulfill the food demand is also increasing in the same way. Consequently, the ever increasing demand for irrigation water and its cost, leading to emphasize on the development and field evaluation of very efficient methods of irrigation that maximize the water use efficiency. Automated drip irrigation is a most efficient method of applying irrigation water to plants automatically as per need.

\section{Materials and Methods}

The field experiment was conducted at Plasticulture Farm, CTAE campus, MPUAT Udaipur, which is situated at $24^{\circ} 35^{\prime} 31.5^{\prime}$ ' North latitude and $73^{\circ} 44^{\prime} 18.2^{\prime \prime}$ East longitude at an altitude of 582.17 meters above mean sea level. The soil type was sandy loam. The 
maximum temperature goes as high as $46{ }^{\circ} \mathrm{C}$ during summer and minimum as low as $5{ }^{\circ} \mathrm{C}$ during winter months.

\section{Conventional and automated drip} irrigation setup details

The experimental systems consists of irrigation pump, Sand and Screen filters, Control valves, Ventury, Bypass valve, Gate valve, End cap, Jointer, Pressure gauges. A PVC pipe of $40 \mathrm{~mm}$ diameter having pressure rating up to $4 \mathrm{~kg} / \mathrm{cm}^{2}$ was used as mainline for conventional drip irrigation. In automated drip irrigation system micro controller, stator relay, automated bypass valve, and solenoid valve were used as extra accessories with conventional drip system. The $16 \mathrm{~mm}$ diameter pipes having inline drippers of $30 \mathrm{~cm}$ spacing and $4 \mathrm{lph}$ discharge was used as lateral for both systems.

\section{Criteria for evaluation}

In this study fifteen drip lines for automated drip system and four drip lines for conventional drip system were selected from head, middle and tail end on the submain. The average emission rate of three emitters was collected in the catch can for 10 minutes duration at the head, middle and tail end on each selected lateral separately. The constant operating pressure of $1.0 \mathrm{~kg} / \mathrm{cm}^{2}$ was maintained during the period of application.

\section{Performance evaluation parameters}

\section{Uniformity Coefficient (CU)}

Uniformity coefficient was calculated as suggested by $\mathrm{Wu}$ and Gitlin (1974) and Christiansens (1942).

Uniformity coefficient $(\%)=100 \times\left(1^{-\frac{\mathrm{D}}{\mathrm{M}}}\right)$

Where,
$\mathrm{D}=$ Average absolute deviation from the mean discharge rate.

$\mathrm{M}=$ mean discharge rate.

\section{Emission Uniformity (EU)}

The following equation as suggested by (Keller and Karmeli, 1974) was used to calculate emission uniformity.

$E U=\left(\frac{\mathrm{Qn}}{\mathrm{Qa}_{\mathrm{a}}}\right) \times 100$

Where,

$\mathrm{EU}=$ emission uniformity, per cent

Qn = average of the lowest $1 / 4$ of the emission point discharges for field data, lph

$\mathrm{Q} \mathrm{a}=$ average emission point discharge of test sample operated at the reference pressure head, lph.

\section{Distribution Characteristic (DC)}

$D C=\frac{\text { Area receiving irrigation depth more than average depth }}{\text { Total wetted area }}$

\section{Results and Discussion}

The data presented in Table 1 revealed that the values of uniformity coefficient, and emission uniformity were highest at the head and decreases with increase in distance along the lateral for both irrigation systems. This trend was possibly occurs due to head loss along the lateral. The maximum values of $\mathrm{CU}$ were $97.5 \%$ and $94.3 \%$ at head under automated and conventional drip irrigation, respectively. The CU value was found to be more than 90 $\%$ for both systems, which shows excellent performance. Similar, results was also reported by Changade et al., (2009). The average values of EU were $94.1 \%$ and $93.6 \%$ 
for automated and conventional drip irrigation, respectively. The average value of EU was

more than 90\%, which results excellent performance of both systems.

Table.1 Evaluation parameter of automated and conventional drip irrigation system

\begin{tabular}{|c|c|c|c|c|}
\hline Evaluation parameter & $\begin{array}{c}\text { Type of drip } \\
\text { system }\end{array}$ & $\begin{array}{c}\text { Head of } \\
\text { lateral } \\
(\mathbf{\%})\end{array}$ & $\begin{array}{c}\text { Mid of } \\
\text { lateral } \\
(\mathbf{\%})\end{array}$ & $\begin{array}{c}\text { Tail end } \\
\text { of lateral } \\
(\mathbf{\%})\end{array}$ \\
\hline \multirow{2}{*}{ Uniformity Coefficient (CU) } & Automated & 97.5 & 96.6 & 95.5 \\
\hline \multirow{2}{*}{ Distribution Characteristic (DC) } & Conventional & 94.3 & 94.5 & 94.1 \\
\hline & Automated & 76.1 & 71.2 & 70.7 \\
\cline { 2 - 5 } & Conventional & 75.7 & 75.7 & 74 \\
\hline \multirow{2}{*}{ Emission Uniformity (EU) } & Automated & 95.4 & 93.9 & 93.1 \\
\hline & Conventional & 93.7 & 93.6 & 93.2 \\
\hline
\end{tabular}

Plate.1 Experimental view of research field during evaluation of systems

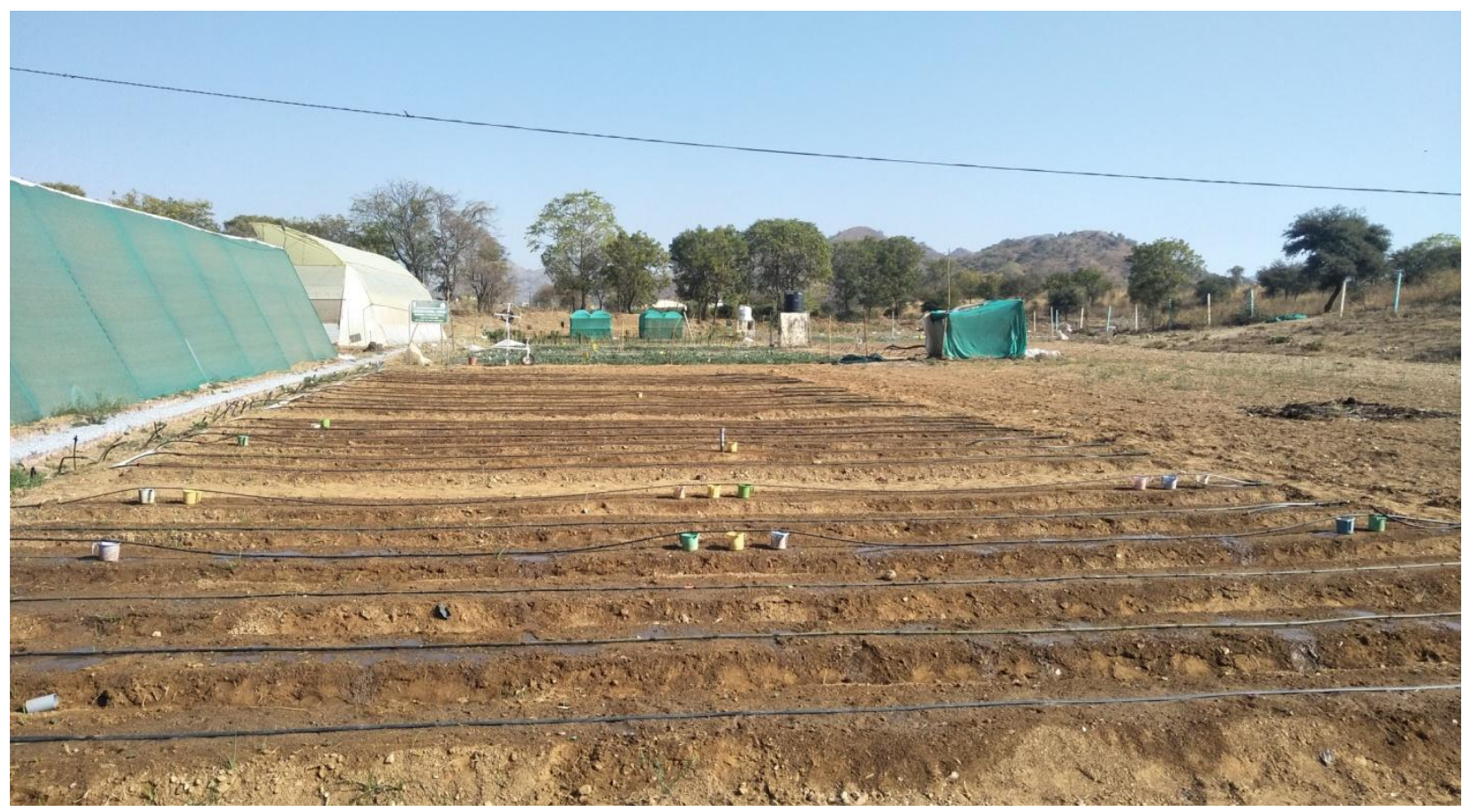

The values of all evaluation parameters were found to be maximum at the head and decreases with increase in distance along the lateral for both irrigation systems. It was also found that the average values of all performance evaluation parameters except DC were found to be highest in automated drip irrigation system as compared to conventional drip irrigation system.
The value of emission uniformity of both systems was more than $90 \%$, which results excellent hydraulic performance of systems.

\section{References}

Arya, C.K. Purohit, R.C. Dashora, L.K. Singh, P.K and Kothari, M. (2017). Performance evaluation of drip 
irrigation systems. Int. J. Curr. Microbiol. App. Sci., 6(4): 2287-2292.

Changade, N.M. Chavan, M.C. Jadhav, S.B and Bhagyawant, R.G. (2009). Determination of emission uniformity of emitter in gravity fed drip irrigation system. Int. J. Agri. Engi., 2(1): 88-91.

Christiansens, J.E. (1942). Irrigation by sprinkling. California Agricultural Experiment Station. Bulletin No. 670. Berkeley.

Keller, J and Karmeli, D. (1974). Trickle irrigation design parameters. Transaction of the American Society of Agri. Engi., 17(4): 678-684.

Kyada, P and Munjapara, B.J. (2013) Study on pressure-discharge relationship and wetting pattern under drip irrigation system. Int. J. Sci. Nat., 4: $274-283$.

Wu, I.P. and Gitlin, H.M. 1974. Drip irrigation design based on uniformity. Transaction of American Society of Civ. Engi., 17: 429-432

\section{How to cite this article:}

Vikas Sharma, Yadvendra Pal Singh, Manpreet Kaur and Paradkar, V.D. 2019. Estimation of Different Uniformities and Distribution Characteristic of Automated and Conventional Drip Irrigation Systems for Okra Crop under Field Condition. Int.J.Curr.Microbiol.App.Sci. 8(07): 2330-2333. doi: https://doi.org/10.20546/ijcmas.2019.807.285 